\title{
Lab-on-a-chip rendszerek a betegágy melletti diagnosztikában
}

\author{
Szabó Barnabás ${ }^{1}$ - Borbíró András ${ }^{1}$. Fürjes Péter ${ }^{2}$ \\ 177 Elektronika Kft., Budapest \\ ${ }^{2}$ Magyar Tudományos Akadémia-Energiatudományi Kutatóközpont-Múszaki Fizikai és Anyagtudományi Intézet, \\ BioMEMS Csoport, Budapest
}

\begin{abstract}
A modern gyógyászat egyre inkább igényli a páciensközeli diagnosztikát a terápiás döntések felgyorsítása vagy akár a laboratóriumi vizsgálatok kiváltása érdekében. Ehhez olyan megbízható, költséghatékony bioanalitikai mérőrendszerek szükségesek, amelyek mintegy mikrolaboratóriumként, integráltan tartalmazzák a biomolekuláris felismerő, érzékelő és jelfeldolgozó, illetve mikrofluidikai mintapreparációs modulokat. Ezek a jórészt mikro- és nanotechnológiai fabrikációs módszerekkel kialakított Lab-on-a-chip rendszerek új távlatokat nyithatnak a gyógyászati ellátás láncolatában, hiszen alkalmasak lehetnek speciális betegségmarkerek vagy azok kombinációinak egy csepp mintából történő, kvantitatív, nagy pontosságú és azonnali kimutatására is. Ennek megfelelően a mérőmúszerekkel és az alkalmazott analitikai módszerekkel szembeni legfőbb követelmények a magas szelektivitás, alacsony alsó mérési határ, rövid válaszidő, integrálhatóság egészségügyi informatikai rendszerekbe. Mindez lehetőséget teremthet a vizsgálatokhoz szükséges hierarchikus lánc rövidítésére is, ezáltal gyökeresen átalakíthatja a laboratóriumi diagnosztikát, új helyzetet teremtve a terápiás intervencióban. Orv. Hetil., 2015, 156(52), 2096-2102.
\end{abstract}

Kulcsszavak: betegágy melletti diagnosztika, in vitro diagnosztika, laboratórium egy chipen, mikrofluidika, bioszenzor, biomarker, információs rendszer

\section{Lab-on-a-chip systems in the point-of-care diagnostics}

The need in modern medicine for near-patient diagnostics being able to accelerate therapeutic decisions and possibly replacing laboratory measurements is significantly growing. Reliable and cost-effective bioanalytical measurement systems are required which - acting as a micro-laboratory - contain integrated biomolecular recognition, sensing, signal processing and complex microfluidic sample preparation modules. These micro- and nanofabricated Lab-ona-chip systems open new perspectives in the diagnostic supply chain, since they are able even for quantitative, highprecision and immediate analysis of special disease specific molecular markers or their combinations from a single drop of sample. Accordingly, crucial requirements regarding the instruments and the analytical methods are the high selectivity, extremely low detection limit, short response time and integrability into the healthcare information networks. All these features can make the hierarchical examination chain shorten, and revolutionize laboratory diagnostics, evolving a brand new situation in therapeutic intervention.

Keywords: point-of-care diagnostics, in vitro diagnostics, Lab-on-a-chip, microfluidics, biosensor, biomarker, information system

Szabó, B., Borbiró, A., Fürjes, P. [Lab-on-a-chip systems in the point-of-care diagnostics]. Orv. Hetil., 2015, 156(52), 2096-2102.

(Beérkezett: 2015. október 5.; elfogadva: 2015. október 29.)

\section{Rövidítések}

$\mathrm{COC}=$ cikloolefin kopolimer; HIS = (hospital information system) kórházi információs rendszer; IVD = in vitro diagnostics; LIS = (laboratory information system) laboratóriumi információs rendszer; LOC $=($ Lab-on-a-chip $)$ laboratórium egy chipen; MEMS = (micro-electromechanical systems $)$ mikroelektromechanikai rendszerek; MSS = (membrane-type surface stress sensor) membrán típusú felületifeszültség-szenzor; NEMS = (nano-electromechanical systems) nano-elektromechanikai rendszerek; OWLS $=$ (optical waveguide lightmode 
spectroscopy) optikai hullámvezető fénymódus spektroszkópia; PDMS = poli-dimetil-sziloxán; PET = polietilén-tereftalát; POCT $=$ (point-of-care testing) betegágy melletti diagnosztika; QCM = (quartz crystal microbalance) kvarckristály mikromérleg; SAW = (surface acoustic wave sensor) felületi akusztikushullám-szenzor; SELEX = systematic evolution of ligands by exponential enrichment; SPR = (surface plasmon resonance) felületi plazmonrezonancia; SU-8 = epoxialapú negatív fotoreziszt anyag

Számos klinikai analitikai teszt célozza a folyadékmintákban jelen lévő diagnosztikai jelentőségú molekulák vagy akár sejtek minőségi és mennyiségi kimutatását. Az innovatív analitikai rendszerek forradalmian új mérési elveken alapuló szenzoreszközöket, reagenseket és nagy teljesítményű mintapreparációs modulokat tartalmaznak, így ezek kompakt formában képesek olyan teljesítményre, amely helyben történő mérés mellett összevethető akár a nagy laboratóriumi eszközökével is. A hagyományosnak mondható kémiai és mechanikai szenzorok területén kezdődő mikrotechnológiai forradalom mára betört a bioanalitikai eszközök területére is, és ezek megvalósításához egyre kiterjedtebben hasznosítják a mikro- és nanotechnológiai kutatások eredményeit. A fejlődő érzékelési elvek új utat nyithatnak a robusztus, költséghatékony és felhasználóbarát analitikai platformok megvalósításának irányában. A komplex bionikai rendszerek fejlesztése és azok diagnosztikai környezetbe történő integrálása több tudományterület szoros együttmúködését követeli meg.

\section{Point-of-care testing, avagy betegágy melletti diagnosztika}

A point-of-care testing (POCT) in vitro diagnosztikai (IVD) eszközök mögött az a vezérelv áll, hogy a diagnosztizálás a kívánt célcsoport által helyben, hatékonyan, azonnali eredménnyel, automatikusan dokumentálva elvégezhető legyen. Ez megteremti a lehetőségét annak, hogy a döntéshez/beavatkozáshoz szükséges objektív adatok rövid idő alatt rendelkezésre álljanak, ezáltal a vizsgálatokhoz szükséges hierarchikus lánc közbenső szintjei is lerövidülnek. A POCT-rendszereket diagnosztikai, gazdasági és társadalmi oldalról vizsgálva számos minőségi és kvantifikálható előnyt hordoznak magukban a diagnosztika terén [1]:

- Lerövidül a diagnosztizálási idő.

- Nem igényel bonyolult laboratóriumi előkészítő folyamatot. A laboratóriumi munkálatok mennyisége, költsége csökken - olcsóbb, költséghatékonyabb teszteket eredményezve.

- Csökken a múszerek mérete (hordozhatóság): ezáltal betegágy mellett, rohamkocsiban vagy klinikumtól távoli területeken (akár elmaradottabb földrajzi területeken), POC is alkalmazhatóak.

- Automatikus dokumentáció által a minőségbiztosítási (LIS/HIS) rendszer fontos részét képezik.
- Általános alapismeretekkel rendelkező felhasználó is biztonsággal képes kezelni az eszközt.

- A kisebb emberi erőforrásigényből fakadóan kevesebb az emberi hibatényező.

- A személyre szabott medicina elveinek érvényesíthetősége is felmerül.

\section{Lab-on-a-chip - laboratórium egy csipen}

A Lab-on-a-chip rendszerek olyan miniatúr diagnosztikai eszközök, amelyek integráltan - mintegy komplett mini- vagy mikrolaborként - valósítják meg a megcélzott
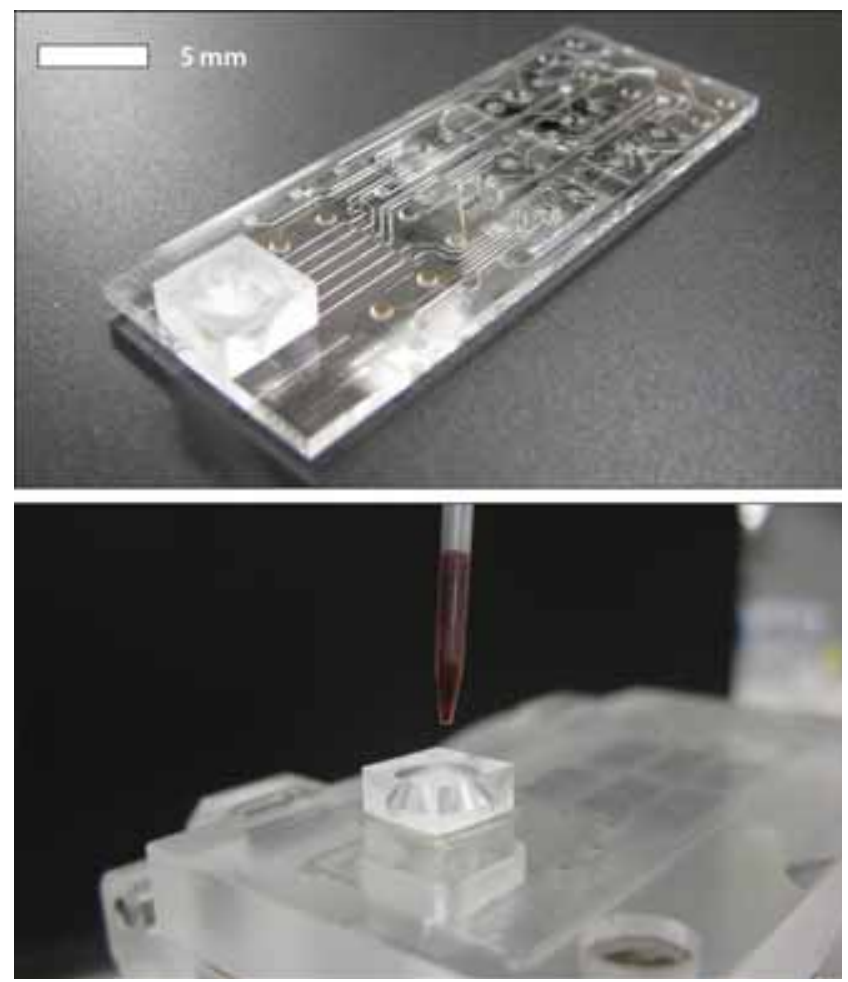

1. ábra

A Lab-on-a-chip rendszerek miniatűr méretben integrálják a mikrofluidikai alapú minta-elókészítő és specifikus érzékelési funkciókat, ezáltal a minta akár előzetes feldolgozás nélkül is mérhető. A képen a 77E, BME, SE, MTA EK MFA MEMS Lab és Micronit által fehérjemarkerek kimutatására fejlesztett elektrokémiai mérócella látható $[2,3,4,5,6]$

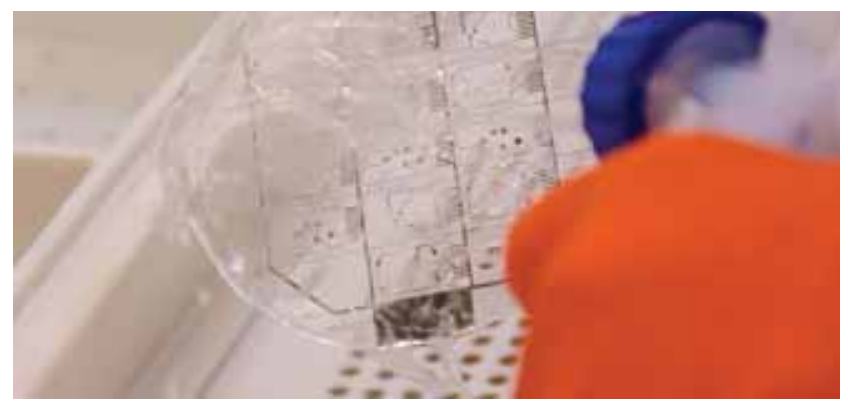

2. ábra A mikro- (vagy akár) nanotechnológiai eljárások (lásd: MEMS, NEMS) alkalmazása lehetővé teszi a diagnosztikai rendszerek miniatürizálását. A képen mikronfelbontású fémrajzolat kialakítása az MTA EK MFA nagy tisztaságú MEMS Laboratóriumában [5] 

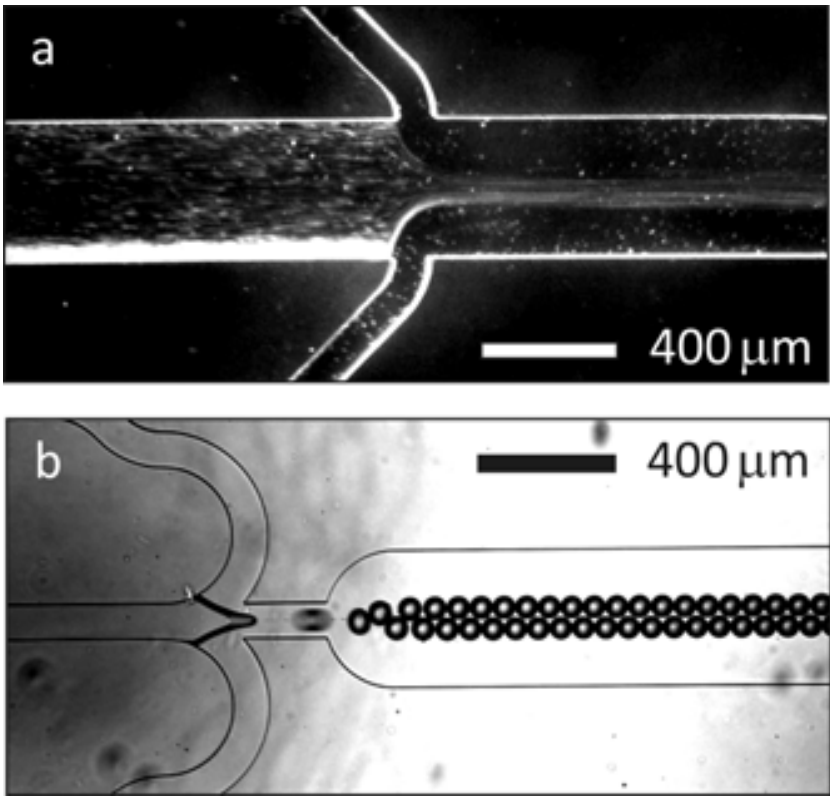

3. ábra

A folytonos (a) és digitális (cseppes) (b) mikrofluidikai rendszerek felhasználása egyre elterjedtebb sejtanalitikai alkalmazások területén is. A képen sejtszuszpenzió fókuszálása (a), illetve sej tek csapdázása folyadékcseppben (b) MTA EK MFA BioMEMS Csoport $[5,9,10]$

analitikai feladat egyes kulcslépéseit, mint a mintagyüjtés, -szállítás, -előkészítés, de tartalmazzák az érzékelővagy a kiértékelőegységet is (1. ábra). Akár egy egészen komplex laborfolyamatot is képesek megvalósítani mikroméretekben, ennek megfelelően minimális mintaigénnyel.

Ezek a komplex eszközök tehát a miniatürizált érzékelőrendszerek és a folyadékkezelési feladatokat ellátó mikrofluidikai szerkezetek integrálásával hozhatók létre (2. ábra), amelyek megvalósítása a robusztus - integrált áramköri elemek kialakítása során évtizedek óta bevett módon alkalmazott - mikromechanikai technológiák segítségével már nem is olyan bonyolult és lehetetlen kihívás.

A Lab-on-a-chip rendszereket alkalmazó koncepcionálisan új diagnosztikai eszközöknek számos előnye van, a méretből adódó hordozhatóságon, vagyis a POC diagnosztikai alkalmazás lehetőségén túl is:

- Kis mintatérfogat: mérés akár egy csepp testfolyadékból (vér, agy-gerincvelői folyadék, ízületi folyadék, nyál, vizelet stb.).

- Költséghatékonyság: minimális reagensigény.

- Érzékenység, pontosság, megbízhatóság jelentős növekedése: akár hagyományos mérési módszereket alkalmazó nagylaboratóriumi berendezések paramétereinek megközelítése vagy felülmúlása.

- Komplex laboratóriumi minta-elókészítési eljárások kiváltása.

- Több paraméter és azok kombinációjának egyszerre történő, gyors és nagy áteresztőképességű mérése.

\section{Mintakezelés mikroméretekben - mikrofluidikai rendszerek}

A mikrotechnológia területén a mechanikai és kémiai érzékelők miniatürizálásán túl egyre inkább előtérbe kerül a bioanalitikai célú mikrofluidikai rendszerek fejlesztése. A mikroméretű, de annál komplexebb áramlási rendszerek alapvetően (orvos)diagnosztikai, analitikai eszközök mintapreparációs feladatait vagy reagensmúveleteit oldják meg kompakt, integrált formában $[7,8]$.

A mikrofluidikai rendszerekben - a komplexitás növekedése mellett - olyan mérettartományokat érhetünk el, amelyek új lehetőségeket és persze kérdéseket vetnek fel mind a lejátszódó fizikai folyamatok, mind a lehetséges alkalmazások tekintetében. Kézenfekvő az extrém kis folyadékmennyiségek (nanoliter) lehetséges manipulációja vonatkozásában kiemelni a mikroskálán megjelenő áramlástani jelenségeket is. A méretek csökkenésével párhuzamosan a fizikai és kémiai folyamatok extrém paraméterfüggést mutatnak, így sok esetben nem triviális, a makroszkopikus tartományban érvényestől merőben különböző fizikai viselkedés azonosítható. Ennek megfelelően a mikro- (és nano-) méretü fluidikai rendszerek vizsgálata és müködésük minél részletesebb megértése alapvető jelentőségü a jövő extrém nagy érzékenységú analitikai, illetve célzott mintapreparációs rendszereinek fejlesztése szempontjából. A folytonos (3. a ábra) és digitális (cseppes) (3. b ábra) mikrofluidikai rendszerek felhasználása egyre elterjedtebb a sejtanalitikai alkalmazások területén is $[9,10]$.

A mikrofluidikai rendszerek alapvető funkciói a teljesség igénye nélkül:

- mintaszállítás,

- szeparáció, filtrálás (kiterjedt részecskék, sejtek - például méret szerinti - válogatása passzív [filtereken, hidrodinamikai erőkön alapuló] vagy aktív [elektro-, magneto-, akusztoforetikus stb.] mikrofluidikai rendszerekben) $[11,12,13]$,

- keverés, például mikroreaktorokban. (Érdemes itt megjegyezni, hogy a mikroszkopikus karakterisztikus méretek miatt az áramlások jellemzően laminárisak alacsony a jellemző Reynolds-szám -, így a keveredés alapesetben csak diffúzióval valósulhat meg.)

A kaotikus advekción alapuló (keresztirányú másodlagos csatornákat is tartalmazó) mikrofluidikai keverőstruktúra viselkedését a 4 ábra mutatja be [14].

A fluidikai rendszerek multifunkciós eszközökben történő integrálása komoly technológiai kihívás, azonban ma már széleskörüen elérhetővé vált az a mikro- és nanomechanikai (MEMS, NEMS) háttéren nyugvó rendszertechnológia, amely mind szilícium/üveg, mind polimer (PDMS, SU-8, PET, COC stb.) alapanyagban lehetővé teszi komplex mikrorendszerek kialakítását. A bioanalitikai eszközök alkalmazhatóságának alapfeltétele, hogy az érzékelőt integráló mikrofluidikai rendszerek a funkcionális megbízhatóság mellett robusztusak, biokompatibilisek, hosszú távon is stabilak legyenek. Emiatt a mikro- 

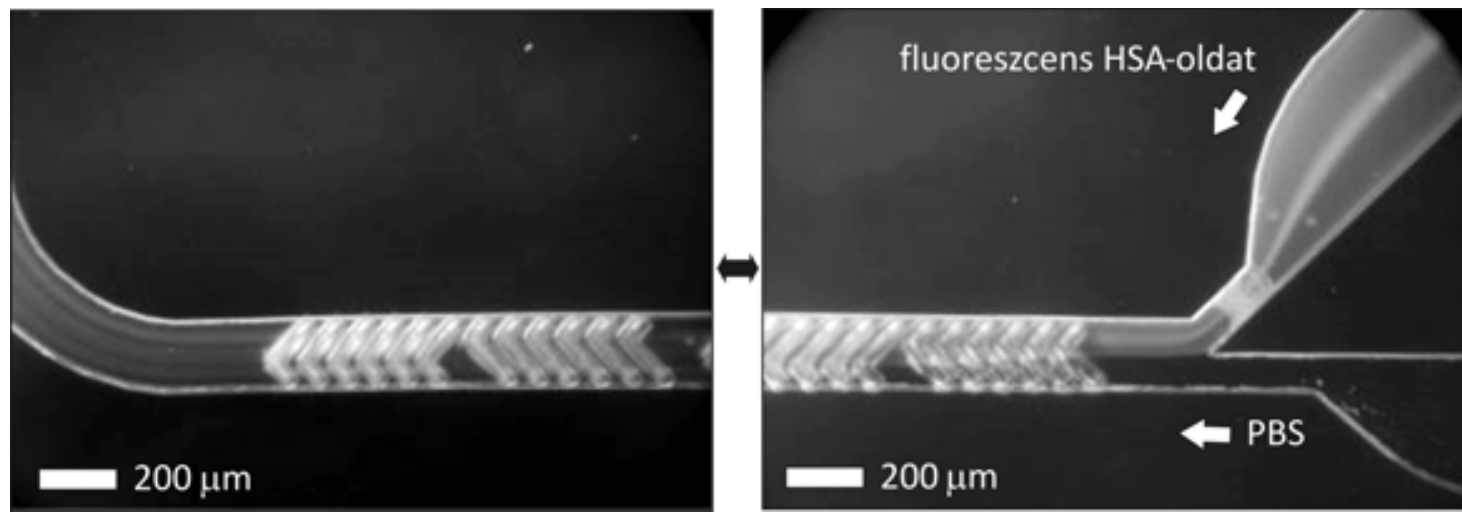

4. ábra

| Kaotikus advekción alapuló (keresztirányú másodlagos csatornákat is tartalmazó) mikrofluidikai keverőstruktúra viselkedése [14]

fluidikai rendszerek esetén alapvető fontosságú az anyagválasztás, a kialakítási technológia és a megfelelő felületmódosítás [15].

\section{Bioszenzorika a diagnosztikában}

A modern molekuláris diagnosztika fontos és gyorsan fejlődő területe a különféle biomarkerek érzékeléstechnológiája is. A minél kisebb mennyiségü minta, az alacsony kimutatandó koncentráció - azaz magas érzékenység -, valamint a minél nagyobb költséghatékonyság elérése újabb és újabb kihívásokat állít a mikrofluidikába integrálandó bioszenzorok fejlesztése terén.

A biokémiai szenzorok fó alkotórészei a molekuláris felismerést, valamint a jelátvitelt megvalósító egységek. $\mathrm{Az}$ érzékelő-felismerő egység a mérendő kémiai paramétert (általában koncentrációt) jól mérhető jellé alakítja a jelátvivő egység számára. Bioszenzorok esetében ez a szelektív felismerési lépés megfelelő biológiai folyamatokra épül, míg a jelátvitel a kiértékelés módjától függően többféle fizikai-kémiai paraméteren vagy jelenségen alapulhat [16].

A biomolekuláris felismerés alapvetően az általános értelemben vett bioreceptor-ligandum kölcsönhatások kihasználásán alapul: megkülönböztethetünk katalitikus aktivitású reakciókon (például enzimek, sejtek esetén), illetve bioaffinitáson alapuló (például antitestek, nukleinsavak, peptid-nukleinsavak, aptamerek, receptorpeptidek, proteinek) felismerő komponenseket. Mint korábban említettük, a felismerési folyamattal szemben támasztott legfőbb elvárások: a magas szelektivitás, az alacsony alsó mérési határ és az alacsony válaszidő. Mivel a bioaffinitás-alapú felismerési folyamat során a célmolekula bekötődése általában csak kevéssé változtatja meg a közeg jelátvivő által érzékelendő fizikai-kémiai tulajdonságát, ezért a kölcsönhatás egyik reakciópartnerét hagyományosan további jelöléssel szükséges ellátni - például fluoreszcens molekulával, enzimmel, radioaktív izotóppal vagy egyéb komponensekkel -, hogy analitikai módszerrel érzékelhető legyen [17]. Annak érdekében, hogy az alkalmazott analitikai - például Lab-on-a-chip - rendszer többféle paraméter együttes mérését is képes legyen elvégezni, a különböző célmarkerekre szelektív felismerő molekulák csoportjait ismert és kontrollált térelosztásban kell immobilizálni az érzékelő - többségében szilárd hordozó - felületén. Ennek megfelelően az egyes érzékelési területeken végbemenő változásokat is egymástól függetlenül kell monitorozni.

Számos hagyományos gyorsteszt esetén a kiértékelés egyszerü - akár emberi szem által megfigyelhető - optikai jelenségen alapul, ennek megfelelően az erre épülő elektronikai készülékek optikai mérőfejjel rendelkeznek. Az ilyen gyorstesztek esetében jellemzően aranykolloid jelölőrészecskéket alkalmaznak előnyös optikai abszorpciós képességük miatt. Szintén elterjedt a fluoreszcens jelölés alkalmazása is, amely esetén a gerjesztő és az érzékelendő fény hullámhossztartománya eltérő, ami méréstechnikai előnyt biztosít. Kvantumpontok, azaz nanométeres nagyságrendbe eső félvezető kristályok használatával szintén fluoreszcens jelölést lehet megvalósítani, ezek előnye, hogy fotostabilitásuk sokkal jobb, mint a szerves fluoreszcens jelölőké.

Meg kell említeni, hogy a jelöléses módszerek mindegyike érzékeny a jelölőanyag minimális mennyiségére, és a jelölő-jelölt kötések létrejöttére ható környezeti tényezőkre. Jelölésmentes jelátvivők és detektálási elvek esetén ezek a problémák elkerülhetőek, hiszen egy lépéssel lerövidül az út a mérendő komponens koncentrációja és a numerikus eredmény között. Ebben az esetben azonban extrém érzékenységú kimutatási elvek alkalmazása válik szükségessé. Ennek megfelelően a hagyományos elektrokémiai, optikai és reakcióhő mérésén alapuló jelátalakítási elvek mellett ki kell emelni az újabb, nagy teljesítőképességgel kecsegtető fejlesztéseket.

Ilyen módszer a felületi plazmonrezonancia (SPR), amely a jelölésmentességen túl további előnyökkel is bír: használatával valós időben meghatározható a biomolekuláris kölcsönhatások kinetikája, valamint további gyenge felületi kölcsönhatások is vizsgálhatók vele. Ez a mérési elv a szubsztrátfelülethez közeli - tipikusan néhány száz nm vastag - tartomány törésmutató-változására érzékeny optikai módszer, hasonlóan az optikai hullámvezető fénymódus spektroszkópiához (OWLS). 


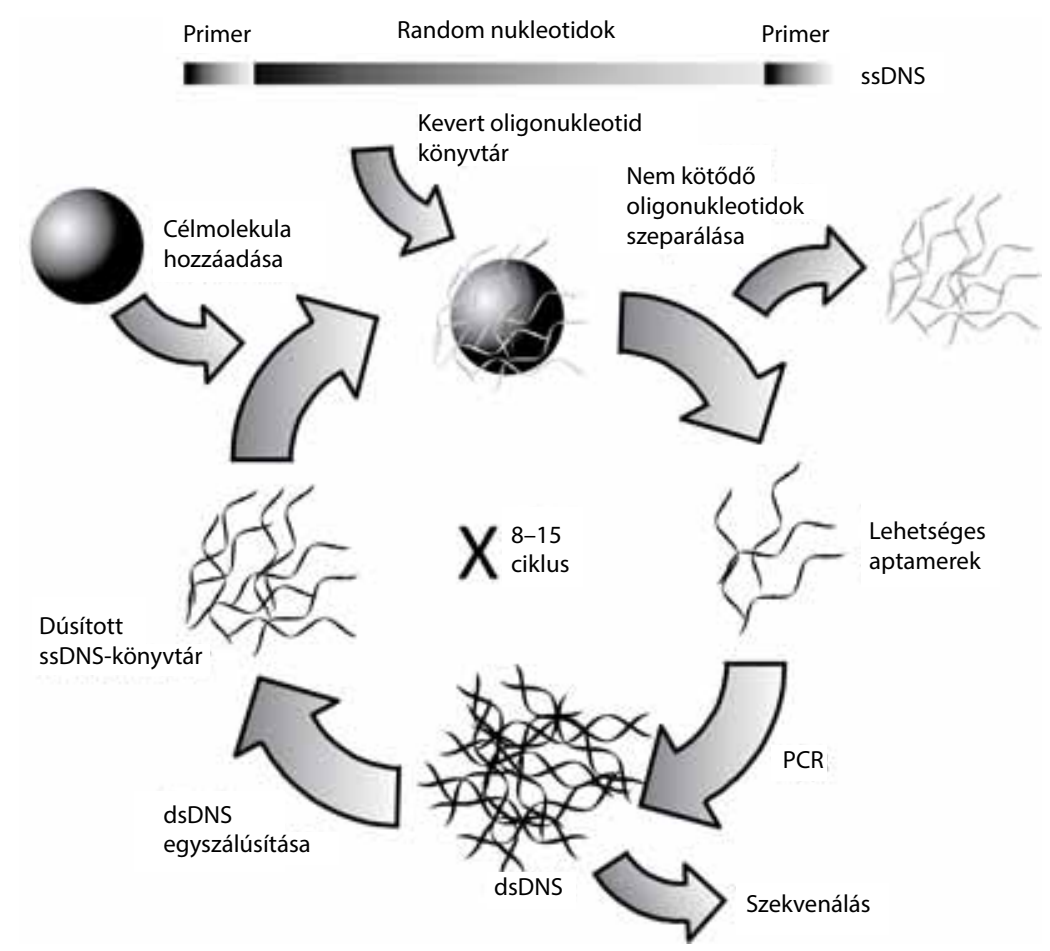

5. ábra

A mikromechanikai bioszenzorok alkalmazása is óriási lehetőségekkel kecsegtet. Ebben az esetben mikro- vagy akár nanoméretű szerkezetek (membránok, felfüggesztett tartók-konzolok stb.) mechanikai tulajdonságainak megváltozásán keresztül azonosítható a mérendő komponensek bekötődése. A korábban vázolt bioaffinitási kölcsönhatás azonosítása érdekében természetesen a szerkezetek felületét megfelelő módon kell funkcionalizálni. A jelátalakítás módja szerint jellemzően statikus és dinamikus érzékelési elv alkalmazható. Az első (statikus) a szerkezet bekötött molekularéteg miatt kialakuló mechanikai feszültségét, deformációját vizsgálja (membrane-type surface stress sensor - MSS). A második (dinamikus) pedig a szerkezet teljes tömegváltozása miatt tapasztalható saját rezonanciafrekvencia eltolódásának mérésén alapul, amire példa a kvarckristály mikromérleg (QCM), a felületi akusztikushullám-szenzor (SAW), a mikrogyürü-rezonátor vagy a mikrokonzol-szerkezetek [18].

A félvezető nanohuzalokat mint térvezérlésű tranzisztorokat alkalmazó kémiai szenzorok mérési elve a tranzisztorcsatorna vezetőképességének változásán alapszik, amelyet a kémiailag érzékennyé tett vezérlőelektróda és a minta oldatának határán lejátszódó reakció befolyásol, ami egyszerű elektromos méréssel követhető [19].

Szintén meg kell említeni az ioncsatorna típusú bioérzékelő rendszereket, amelyek a célmolekulával összemérhetô és azzal szelektíven reagálni képes nanopórusokat tartalmazó elektromosan szigetelő membránon alapulnak. Bekötődési kölcsönhatás esetén a membrán ionáteresztő képessége csökken, így a membránon áthaladó, nagy koncentrációban jelen lévő ionok árama változik.
Ennek megfelelően az ionok fluxusa nagyon érzékeny a bekötött komponensek számára, így akár egyetlen molekula is érzékelhető ily módon. Az egyre finomodó, mikro- és nanotechnológiai eljárásokon alapuló megmunkálással elóállított érzékelőszerkezetek a megfelelő bioreceptorokkal párosítva adnak lehetőséget a nagy pontosságú diagnosztikai rendszerek megszületésére [20].

\section{Új típusú diagnosztikus biomarkerek}

Napjaink diagnosztikai eljárásai döntőrészt adott biomarkerek (például DNS-szálak, fehérjék) kimutatására irányulnak. A nukleinsav-biomarkerek detektálása általános metodikák alkalmazásával kivitelezhető, mivel ezen makromolekulák sokszorozása hibridizáción, illetve szekvenáláson alapuló specifikus azonosítása már-már rutineljárásoknak tekinthetők. A diagnosztikailag releváns fehérjék specifikus mérése jelenleg komolyabb kihívást jelent. A tradicionálisabb megközelítés az adott fehérjék jellegzetes enzimaktivitását aknázza ki, ily módon közvetetten, a mért aktivitásból határozza meg a vizsgálandó fehérje koncentrációját. A második lehetőség, a fehérje közvetlen detektálása szélesebb körben alkalmazható, mert enzimaktivitással nem rendelkező fehérjék kimutatását is lehetővé teszi, azonban ennek a megközelítésnek elengedhetetlen feltétele a nagyfokú szelektivitással rendelkező receptorok elérhetősége. Napjainkban a szükséges receptorok funkcióját túlnyomórészt az ellenanyagok töltik be, azonban egyre növekszik az alkalmazott mesterséges receptorok (például mesterségesen megtervezett oligonukleotid láncok) jelentősége is [21]. 
Ismert, hogy az egyszálú nukleinsavak bonyolult térszerkezeteket hozhatnak létre, amely tulajdonság képessé teszi őket fehérjék és kis molekulák szelektív felismerésére és megkötésére. Negyedszázada jelentek meg az első közlemények, amelyek igazolták, hogy megfelelő számú, mintegy $10^{12}-10^{14}$ random szekvenciával rendelkező oligonukleotidot tartalmazó DNS- vagy RNSkönyvtárból in vitro szelekcióval elméletileg tetszőleges fehérjét, kis molekulát felismerő oligonukleotidok izolálhatók. A szelektív kötőképességgel rendelkező egyszálú DNS-ek, RNS-ek aptamer néven váltak ismertté, míg az előállításukra alkalmazott iteratív eljárás a SELEX elnevezést kapta $[22,23,24]$. A SELEX-módszer lépéseit az 5. ábra mutatja be.

Az aptamereket a szakirodalom az ellenanyagok alternatívájaként kezeli, előállításuk semmiféle élő organizmust nem igénylő in vitro folyamat. A sikeres ellenanyaggenerálás elengedhetetlen feltétele, hogy az antigén megfelelő immunválaszt váltson ki, míg aptamer elméletileg bármilyen molekulára szelektálható. Szemben az ellenanyagokkal, az aptamerek összetétele pontosan ismert, így kémiai szintézissel, mindig azonos minőségben gyorsan, költséghatékonyan, tetszőleges mennyiségben állíthatók elő.

A diagnosztikai alkalmazás szempontjából kiemelten fontos, hogy az oligonukleotidok tárolása nem igényel speciális körülményeket, funkcionalitásukat szobahőmérsékleten is évekig megőrizhetik, amelynek következtében az aptamer receptoralapú mikrofluidikai szenzorok várható életideje hosszabb, míg előállítási és tárolási költsége alacsonyabb az ellenanyagokon nyugvó diagnosztikai készletekhez képest [25].

A target-receptor (antitest-antigén) kötődésen alapuló bioérzékelési koncepció magában hordozza az egy adott érzékelési elvet megbízhatóan alkalmazó Lab-on-a-chip analitikai eszközök gyors bővítési lehetőségét is ismert vagy új specifikus célmarkerek implementálására. Néhány potenciális alkalmazási terület a fehérjék, metabolitok és patogén organizmusok mérése. Az integrált mikrofluidikai kazetta lehetőséget teremt a többféle - akár speciális - biomarker párhuzamos mérésére is adott mintából, amely bioinformatikai módszerek segítségével akár az egyénre szabott vizsgálatok alapja lehet hosszú távon.

\section{Gyorsabban, érzékenyebben, megbízhatóbban}

$\mathrm{Az}$ orvosi diagnosztikai rendszerekkel szembeni magas minőségi és megbízhatósági követelmények miatt a hosszú távú cél ultraszenzitív, akár egyes molekulákat is analizálni képes, kis méretü, gyors és olcsó rendszerek megteremtése. Komplexitásuk miatt egyértelmú, hogy a mikrofluidikába integrált, megfelelő receptormolekulákat alkalmazó bioérzékelő rendszer, valamint az elektronikai kiolvasóeszköz létrehozásához és rendszerré történő fejlesztéséhez multidiszciplináris tudásra, a különböző tudományterületek szoros együttmúködésére van szükség.

Ezek a Lab-on-a-chip rendszerek új távlatokat nyithatnak a diagnosztikai ellátás módszertanában, lehetővé téve akár speciális biomarker-kombinációk egy csepp mintából történő nagy pontosságú, kvantitatív mérését is. Kiemelendő, hogy a LOC-alapú POC diagnosztikai rendszer rugalmas használata alkalmat ad az egyénre szabott vizsgálati eljárások megvalósítására is, ezáltal gyökeresen átalakíthatja a laboratóriumi diagnosztikát, új helyzetet teremtve a terápiás intervenció hatékonyságában. Az új, betegágy melletti rendszerek az e-health követelményeknek megfelelő minőségi, hálószerû LIS/HIS rendszert alkalmazó labordiagnosztika kialakítását is lehetővé teszik.

Az új eszközrendszer biztosítja új protokollrendszerek kiszolgálását diagnosztikai, népegészségügyi, szűrési feladatok ellátására, otthoni monitorozásra és akár diagnosztizálásra is alkalmas lehet. Összességében az egészségügyi ellátás javuló minősége, az orvosi, laboratóriumi terhek csökkenése várható a diagnosztizálás, monitorozás során az új, betegágy melletti Lab-on-a-chip eszközök által, amelyek jól összehangolhatók más korszerú technológiákkal, a telemedicinával és e-health rendszerekkel is. Alkalmazásukkal mód nyílik a diagnosztikai és terápiás algoritmusok egységes kidolgozására, alkalmazására, és megteremtik az alapját egy egészségügyi szempontból előnyösen alkalmazható adatbázisnak is.

Anyagi támogatás: A közlemény megírása, illetve a kapcsolódó kutatómunka a Nemzeti Kutatási, Fejlesztési és Innovációs Hivatal VKSZ_14-1-2015-0004 azonosítószámú pályázata által anyagi támogatásban részesült.

Szerzői munkamegosztás: B. A., Sz. B.: A szakirodalmi rész feldolgozása, a kézirat megszövegezése. F. P.: Tanácsadás, a szakirodalmi rész feldolgozása, a kézirat megszövegezése, a végleges szöveg lektorálása. A cikk végleges változatát valamennyi szerző elolvasta és jóváhagyta.

Érdekeltségek: A szerzőknek nincsenek érdekeltségeik.

\section{Köszönetnyilvánítás}

Köszönjük Dr. Gyurcsányi E. Róbertnek, Dr. Mészáros Tamásnak és Dr. Mátyus Péternek, hogy tudásukkal és nélkülözhetetlen szakmai tanácsaikkal segítették munkánkat.

\section{Irodalom}

[1] Yager, P., Edwards, T., Fu, E., et al.: Microfluidic diagnostic technologies for global public health. Nature, 2006, 442(7101), $412-418$.

[2] www.e77.hu [Last accessed: 18 November 2015]

[3] www.biochemsens.bme.hu [Last accessed: 18 November 2015]

[4] www.semmelweis.hu/orvosi-vegytan [Last accessed: 18 November 2015] 
[5] www.mems.hu, www.biomems.hu [Last accessed: 18 November 2015]

[6] www.micronit.com [Last accessed: 18 November 2015]

[7] Sackmann, E. K., Fulton, A. L., Beebe, D. J.: The present and future role of microfluidics in biomedical research. Nature, 2014, 507(7491), 181-189.

[8] Whitesides, G. M.: The origins and the future of microfluidics. Nature, 2006, 442(7101), 368-373

[9] Xuan, X., Junjie Zhu, J., Church, C.: Particle focusing in microfluidic devices. Microfluids and Nanofluids, 2010, 9(1), 1-16.

[10] Zhao, C. X., Middelberg, A. P.: Two-phase microfluidic flows. Chem. Eng. Sci., 2011, 66(7), 1394-1411.

[11] Sajeesh, P., Sen, A. K.: Particle separation and sorting in microfluidic devices: a review. Microfluids and Nanofluids, 2014, 17(1), $1-52$.

[12] Tripathi, S., Bala Varun Kumar, Y. V., Prabhakar, A., et al.: Passive blood plasma separation at the microscale: a review of design principles and microdevices. J. Micromech. Microeng., 2015, 25(8), 083001

[13] Fekete, Z., Nagy, P., Huszka, G., et al.: Performance characterization of micromachined particle separation system based on Zweifach-Fung effect. Sensors Actuators B: Chemical, 2012, 162(1), 89-94.

[14] Tóth, E. L., Holczer, E. G., Iván, K., et al.: Optimized simulation and validation of particle advection in asymmetric staggered herringbone type micromixers. Micromachines, 2015, 6(1), 136150

[15] Fürjes, P., Holczer, E. G., Tóth, E., et al.: PDMS microfluidics developed for polymer based photonic biosensors. Microsyst. Technol., 2015, 21(3), 581-590.

[16] Tóth, K., Gyurcsányi, R. E.: Sensors in analytical chemistry. [Szenzorok az analitikai kémiában.] Magyar Tudomány, 2002, 12, 1614-1623. [Hungarian]
[17] Gyurcsányi, R. E.: Trends in the analytical transduction of bioaffinity based molecular recognition events. [Új irányok a biomolekuláris felismerés detektálásában.] Magyar Kémiai Folyóirat, 2005, 111(3), 133-142. [Hungarian]

[18] Arlett, J. L., Myers, E. B., Roukes, M. L.: Comparative advantages of mechanical biosensors. Nat. Nanotechnol., 2011, 6(4), 203215.

[19] Zhang, G. J., Ning, Y.: Silicon nanowire biosensor and its applications in disease diagnostics: A review. Anal. Chim. Acta, 2012, $749,1-15$.

[20] Gyurcsányi, R. E.: Chemically-modified nanopores for sensing. Trends Anal. Chem., 2008, 27(7), 627-639.

[21] Borrebaeck, C. A.: Antibodies in diagnostics - from immunoassays to protein chips. Immunol. Today, 2000, 21(8), 379-382.

[22] Stoltenburg, R., Reinemann, C., Strehlitz, B.: SELEX - a (r)evolutionary method to generate high-affinity nucleic acid ligands. Biomol. Eng., 2007, 24(4), 381-403.

[23] Tuerk, C., Gold, L.: Systematic evolution of ligands by exponential enrichment: RNA ligands to bacteriophage T4 DNA polymerase. Science, 1990, 249(4968), 505-510.

[24] Ellington, A. D., Szostak, J. W.: In vitro selection of RNA molecules that bind specific ligands. Nature, 1990, 346(6287), 818822.

[25] Jayasena, S. D.: Aptamers: an emerging class of molecules that rival antibodies in diagnostics. Clin. Chem., 1999, 45(9), 16281650 .
(Szabó Barnabás, Budapest, Fehérvári út 98., 1116 e-mail: bszabo@e77.hu)

\section{Tisztelt Szerzőink, Olvasóink!}

Az Orvosi Hetilapban megjelenő/megjelent közlemények elérhetőségére több lehetőség kínálkozik.

Rendelhetö különlenyomat, melynek áráról bővebben a www.akkrt.hu honlapon (Folyóirat Szerzöknek, Különlenyomat menüpont alatt) vagy Szerkesztőségünkben tájékozódhatnak.

A közlemények megvásárolhatók pdf-formátumban is, illetve igényelhető Optional Open Article (www.oopenart.com).

Adott dij ellenében az online közlemények bárki számára hozzáférhetök honlapunkon (a közlemények külön linket kapnak, igy más oldalról is linkelhetővé válnak).

Bővebb információ a hirdetes@akkrt.hu címen vagy különlenyomat rendelése esetén a Szerkesztőségtől kérhető. 